\title{
Environmental degradation as a security threat: The challenge for developing countries
}

\author{
Ayhan Akbulut ${ }^{1}$
}

\begin{abstract}
The developments after industrial revolution have brought environmental degradation to the stage as a threat to human security in the last few decades. It has become obvious that the shortage of natural resources or negative changes in environmental conditions may lead different forms of conflict between states. Since environmental degradation may directly or indirectly cause a conflict, it will have a significant impact on international security. This problem mostly challenges developing countries on the edge of making a choice between rapid industrialism and environmental conservation. This paper analyzes this challenge by discussing the details of it and offering both national and international level solutions. The zeal for economic growth, enclosure of land and knowledge, and disenfranchisement compose the major challenges for developing countries. There is no easy way to meet those challenges; however, this study offers regional economic integration by cooperation with regional environmental issues, the avoidance of politics leading degradation, dealing with disenfranchisement, environmental education, protection of global commons more seriously, and strict legislation and sanctions against environmental crimes as the steps against environmental threat.
\end{abstract}

Keywords: Environmental Security, Environmental Threat, Environmental Degradation, Environmental Crime, Environmental Protection.

\section{Introduction}

The developments after industrial revolution especially in the last half century resulted in a number of significant outcomes in terms of environmental degradation. Depletion and degradation of natural resources, soil erosion, fuel wood shortage, air and water pollution, extinction of species are among the consequences caused by mostly industrial developments of the century.

These developments have brought environmental degradation to the stage as a threat to human security in the last few decades. As a result, the concept of environmental security/protection has

\footnotetext{
${ }^{1}$ Ph.D., Turkish National Police HQ, ayh akbulut@yahoo.com
} 
Akbulut, A. (2014). Environmental degradation as a security threat: The challenge for developing countries. International Journal of Human Sciences, 11(1), 1227-1237. doi: 10.14687/ijhs.v11i1.2894

been a buzzword for not only states but also international organizations in this course. Environmental degradation is accepted as threat at global, national and individual level.

The shortage of resources or the changes in environmental conditions may lead different forms of conflict between states. The report of the UN working group in 2004 is one of the major declarations of environmental threat. According to the report Environmental issues can be a threat against global, national, and individual security. These are land degradation, climate change, quality and quantity of water resources, management and distribution of natural resources. These issues both may be direct causes of conflict or may be related to conflict by triggering others such as poverty, migration, weapons proliferation and infectious diseases. Environmental degradation will have a significant impact on international security by causing severe competition for domination of resources. This competition will destabilize the weaker states and cause humanitarian crisis. To avoid conflict and build peace, environmental issues and natural resources should be managed properly (UN, 2004).

The aim of this paper is to analyze the major challenge of environmental degradation in developing countries from the point of international security and to offer some resolutions both national and global level. For this sake: firstly the major challenges for environmental degradation are discussed substantially, and then local and international resolutions are offered to cope with the challenges. After the explanations of the serious consequences of environmental degradation in terms of human security, the paper concludes with a special stress on local and global level struggle against environmental threat.

\section{The Challenge of Environmental Degradation for Developing Countries}

The world population is increasing every year in a growing pace. Estimates by the UN Population Fund show that the total world population that 7.2 billion in mid-2013, will reach 8.1 billion in 2025, and to further increase to 9.6 billion in 2050 and 10.9 billion by 2100 (UNFPA, 2013). This situation brings some special responsibilities especially for developing countries where the highest increase in population is observed, and biggest part of the total world population is and will be living (Barbier, 1997). Despite the claims that say the world has enough capacity for 50 billion humans, those claims do not remove the environmental degradation problems and responsibility of paying very special attention to keep environment livable for the humanity. Among all the environmental problems, depletion and degradation of tropical forests, soil erosion, fuel wood shortage, air and water pollution, extinction of species and reduction in biological diversity or genetic erosion are the first priority environmental threats in the developing countries (Buzan and Wæver,1998). 
Akbulut, A. (2014). Environmental degradation as a security threat: The challenge for developing countries. International Journal of Human Sciences, 11(1), 1227-1237. doi: 10.14687/ijhs.v11i1.2894

Globalization has enormous effects on environmental degradation. Especially economic globalization has provided free market economics with ideological and political victories that leaded a substantial change in the world's economic structure. It has also introduced international division of labour, because of low cost and comparatively unregulated work standards in developing countries (McMichael, 2000). So, taking into consideration those two factors, it is obvious that environmental degradation is directly linked to "...the rise of the fossil fuel economy and the decreasing distance of time and space in the relations between different parts of the globe." (Kütting and Rose, 2006:116).

Under those circumstances, developing countries have preferred to invest on regional economic integration as a cure for pressure of globalization and to avoid marginalization. Because economic growth has taken the first priority, they have ignored environmental concerns while developing and implementing trade liberalization measures at regional levels (Zhang, 2001).

Enclosure of land and knowledge has been another significant challenge of environmental degradation for developing countries since the beginning of colonialism in the sixteenth century when capitalist economic system and first wave of European enclosure movement emerged. The worldwide process of privatization and commodification of land, ocean, and atmosphere was also begun with the onset of capitalism. Since capitalism tended to expand and incorporate raw material resources and markets for more profits, enclosure led the national economies to integration and moved them to the international scope by transferring to the colonies. Capitalism started the tragedy for commons, land, oceans, forests, and seeds through the commodification and privatization of knowledge and land. Enclosure also led the movement of the advantages of knowledge and land from the weak to the strong under the effect of the power of capital. With those pressures, the monopoly of knowledge was created for the owners by using patents not to allow others to use common knowledge. So, enclosure of the both knowledge and land have exceeded the existing inequities, and created societal and environmental degradation (Miller, 2001).

Miller gives the example of the British enclosure movement for a better understanding of the enclosure of land. The enclosure of the European commons, beginning more than 7 centuries ago, increased its pace in the 15th century, with the alteration of the economic relationship among the people and between people and environment. The enclosure after the 15th century resulted in two important social and economic consequences in England. First has been the creation of many landless people; and the second has been the encouragement of bourgeoisie and urbanized population. As the ultimate outcome, the industrialization occurred, and caused the disruption of agricultural land, forests and natural rhythm (Miller, 2001). 
Akbulut, A. (2014). Environmental degradation as a security threat: The challenge for developing countries. International Journal of Human Sciences, 11(1), 1227-1237. doi: 10.14687/ijhs.v11i1.2894

The case of Kenya is an example for the British enclosure movement. The economic structure of Kenya totally changed after becoming a British protectorate in 1895. In Kenya, where there had not been individual ownership, the nomadic and the sedentary groups had been the main components of the domestic economy before the British enclosure. Although, there were some minor conflicts because of the abundant land, they protected their resources and environment. However, the situation changed after the colonization. Kenya's economic and politic structures were almost completely transformed and linked to the capitalist world economy. Because, the European settlers taken the fertile land from the natives, many peasants became wage laborers, and lost their economic independences. In the end, in 1963, just before the independence of the country, the native people of Kenya were given the opportunity to regain their land by the colonial government. However, they had to pay high prices to regain their old common properties. Under the colonial system, enclosure process resulted in the creation of two different classes; small elite, who benefited the virtues of the colonialism disproportionately on one side; and many African cheap wage laborers, who faced to negative social, political and environmental consequences on the other side. At this process, also the balance between soil replenishment and plant was ignored; land scarcity and population pressure brought environmental problems including soil degradation, deforestation and desertification. Today, the negative consequences of the enclosure couldn't be removed yet. The case of Kenya still stands an example of sacrificing of nature and people for more profits in the colonial capitalist system (Miller, 2001).

Another kind of enclosure is the enclosure of local knowledge by corporations. The case of neem tree in India is probably one of the best examples of this kind of enclosure. Traditionally, neem tree has been used for the production of pesticides and medicines for many years by the local people of India. However, some multinational corporations from U.S. and Japanese have paid attention to the characteristics of the neem and have usurped traditional common knowledge of the neem by taking out patents for some kinds of neem products, and caused to erosion of diversity. The use of intellectual property rights on the local knowledge of the neem damaged the traditional rights, agricultural infrastructure and reduced genetic diversity. Then, it diminished resilience to pests, disease and environmental stress. In 1970s, the new India's Patents Act obstructed patents on pesticides and fungicides. Fortunately, Indian government changed its policy according to World Trade Organization's (WTO) requirements and accepted the patent protection about agricultural and pharmaceutical areas not to have sanctions by WTO, after 1998 (Miller, 2001).

In both cases, the enclosure of land in Kenya and the enclosure of knowledge in India, there are some common features. First, each case reflects the effects of colonialism by the enclosure of 
Akbulut, A. (2014). Environmental degradation as a security threat: The challenge for developing countries. International Journal of Human Sciences, 11(1), 1227-1237. doi: 10.14687/ijhs.v11i1.2894

common property, resulting in decreased or gone access and inequity. Second, the knowledge and the land were commodified, and the resources were used in favor of the colonist states and their representatives. Whereas, British colonial system forced and used the Kenyan political elite in Kenya case, transnational corporations forced and used the Indian political elite, in neem case. Finally, in both cases the inevitable result has been tragedy for both nature and society (Miller, 2001).

Despite the fact that developing countries have equal legal standing in negotiations and United Nations' (UN) give them high support, disenfranchisement is still another challenge for developing countries to progress sustainable development of environmental issues. Although, developing countries and representatives of civil society are widely accepted as crucial elements for the international policy making, they don't have power enough to affect decision making in international arena, yet. Some of the factors contributing the disenfranchisement of developing countries and their civil society actors in the multilateral arena are the lack of indigenous resources, transnational connectivity and geopolitical status (Fisher \& Green, 2004).

United Nations' Brundtland Commission declared that growing population is a serious problem for environmental degradation in developing countries (Chatterjee \& Finger, 1994). In terms of growing population, poor households, generally living in rural areas and depending on the agricultural productions as their income source compose a significant problem for environmental degradation in developing countries. Generally, what these people have are only land and unskilled labour. Few of them have capital. As a conventional household model, their production and consumption patterns have significantly affected the environment. This effect has emerged from their production and consumption decisions. For instance, the amount and type of fuelwood energy that was used by households do not only affect emissions of greenhouse gasses but also lead deforestation. (Bulte et al, 2001)

In contrast to the recommendation of the commission that advises more development and equitable access to resources to deal with population growth, the reality is that rich countries consume more than poor ones. Despite the fact that only quarter of the world population live in the northern countries, their paper consumption is many times more than other $75 \%$ of the world population living in the South. According to the International Energy Outlook 2013 biggest consumers of the energy of the entire world are incomparably northern countries (IEA, 2013). All those indicators show that economic growth is not a cure for environmental degradation but it leads to more consumption, and so more pollution. Redistribution and de-industrialization seem to serve the global environment more than further economic growth.” (Chatterjee \& Finger, 1994) 
Akbulut, A. (2014). Environmental degradation as a security threat: The challenge for developing countries. International Journal of Human Sciences, 11(1), 1227-1237. doi: 10.14687/ijhs.v11i1.2894

Unlimited expectations led to the demand for more and more consumption. "The social and structural origins of environmental degradation can be found in the excessive consumption of the planet's resources" (Kütting and Rose, 2006:127). As the result of this excessive consumption the world has faced to ecological collapse. If the developed countries had not expended the resources of other countries for their unlimited consumption habits, existing resources would have been able to redistributed more equitably. Today, still the aim of the global economy is to have cheapest, efficient and enough production for the consuming elite of the planet. (Kütting and Rose, 2006)

\section{Resolutions}

There is no easy solution to the problem of environmental degradation especially for the developing countries having to make a choice between rapid industrialism and environmental conservation. However, there are some steps which should be taken to reduce the risks. Regional economic integration by cooperation with regional environmental issues should be promoted for developing countries. The policies leading environmental degradation should be avoided. Developing countries should deal with disenfranchisement and increase their capacity of representation in international area. Environmental education and so awareness should be improved parallel to the industrial development. Military industries as one of the most polluter industry of the world should be regulated strictly. Global commons should be protected by nation states and international actors rather than self solutions. And of course environmental crimes should be taken into consideration and sanctioned strictly by the states and international organizations to avoid further security risks.

Because developing countries are at a point for choice of either the short-run technological gains or the long-run environmental conservation (Chandra, Nivas, and Traxler, 1996), regional economic integration should be promoted but this time by cooperation with regional environmental issues (Zhang, 2001).

"Win-Win" policies of the developing countries led them to reduce import tariffs and export taxes. For example, Philippines reduced those rates of fertilizer, pesticide and other subsidies for irrigated rice, and Indonesia reduced the rate of upland degradation. Although, some developing countries undergo structural reforms, some of critical distortions still affect land degradation and deforestation. Those kinds of policies have increased environmental degradation as an unintended side effect; therefore, they should be mitigated. (Barbier, 1997)

Developing countries should pay special attention to human resources, including their training and knowledge to deal with disfranchisement. Representatives must improve their English ability, since 
Akbulut, A. (2014). Environmental degradation as a security threat: The challenge for developing countries. International Journal of Human Sciences, 11(1), 1227-1237. doi: 10.14687/ijhs.v11i1.2894

it is very important to communicate with other participants and represent his country effectively. Their capacity for decision making process also must be at a certain level. They must be able to determine what decisions are taken at certain meetings and what the impacts of those decisions are. Policy issues, country positions and negotiating blocks are other phenomenon's that they need to be aware of. Therefore, developing countries should give special importance to education, training, and recruitment of delegates for international negotiations, and they also should try to have effective representation in UN bodies, commissions, subsidiary and working bodies to access to information (Fisher \& Green, 2004).

Key factor in international regimes may come from the power from money, military capability, strategic alliances, natural resources or some other combinations. However, geopolitical status is another key factor in international regimes which most of the developing countries naturally have. Civil society organizations are the actors that can use the advantage of the national geopolitical status of the countries. There are several civil society actors, gaining influence from their specific national context. For example, international NGO Friends of the Earth is more capable of participating in and influencing climate change regimes than many others, because its international secretariat is based in Netherlands that is one of the wealthy and world leaders in conducting efforts to slow climate change. Having natural resources is also crucial to determine geopolitical status. For example, because it could affect its biotechnology industry, the U.S. was opposed to biosafety protocol, however developing countries, having the majority of the world's biodiversity, motivated their civil society actors and strengthened an alliance among nations to protect their biodiversity. In the end, the protocol forced into in 2003. Furthermore, countries sometimes might gain power from their proximity to geopolitical leaders (Fisher \& Green, 2004).

Some international institutions also may affect the disenfranchisement process of developing countries and civil society actors. Some of them may have easily accessible and transparent rules such as Commission on Sustainable Development, whereas others have restrictions such as the World Trade Organization. The lack of participation of developing countries and civil society actors will slow collective progress for sustainable future (Fisher \& Green, 2004).

According to Brundtland Commission, large population, poverty, shifting agriculture and logging policies are the significant causes of environmental degradation. Commission recommends that environmental destruction, species, biodiversity and nature all should be included in the national development policies. New technologies should be applied for the protection of species. Ecological rationality and community knowledge shouldn't be ignored. Agricultural methods, use of fertilizers 
Akbulut, A. (2014). Environmental degradation as a security threat: The challenge for developing countries. International Journal of Human Sciences, 11(1), 1227-1237. doi: 10.14687/ijhs.v11i1.2894

and pesticides should be subjects of the education of agricultural populations in developing countries (Chatterjee \& Finger, 1994).

As mentioned before rich countries consume and pollute more than poor countries. That is mainly because of poverty. So, if developing countries become richer, they will also pollute more. Since, industrial development is inevitable, resource and energy saving technological improvements should be made, farming technologies should be improved, and education level of the people must be increased in accordance with the development rates of the countries. (Chatterjee \& Finger, 1994) The increasing rates of awareness and understanding of the environment through education of the people would be a cure for environmental degradation in developing countries (Crowder and et al, 1998).

The military is one of the largest polluters of the world with the amount of toxic waste it produces, the energy it consumes, and the pain and deaths it causes. Therefore, in terms of military, the crucial step is to regulate military industries and stop encouraging the production, the import and export of the weapons. Providing more security, and so decreasing the need of weapons through international agreements and cooperation, would be another crucial step to avoid military pollution. According to Brundtland Commission the management of environmental problems is directly linked the management of military and political conflicts, and it suggests "joint management" and "multilateral procedures and mechanism" in the same way as it was solved in the history (Chatterjee \& Finger, 1994).

Another important point that Brundtland Commission report explains is the protection of global commons. Over exploitation of the oceans through fishing, pollution from toxic dumping, careless disposal of nuclear waste in the space orbits are very dangerous for environment. So, the commission suggested international cooperation instead of self interest. The commission also refers to the traditional "commons" and suggests that the global commons should be managed by nationstates instead of traditional communities, and management of the global commons should be simultaneous with resource and risk management (Chatterjee \& Finger, 1994).

Lastly, the concept of environmental crime and struggle against environmental crime should be taken into consideration and sanctioned strictly by the states and international organizations to avoid further security risks. Concomitant to the emergence of the concept of environmental security the concept transnational environmental crime is increasingly being the subject of international affairs on security. The UN's Convention Against Transnational Organized Crime states that "criminal activities affecting the environment, once an emerging threat, have evolved to become a serious form of transnational organized crime with links to other crimes associated with 
Akbulut, A. (2014). Environmental degradation as a security threat: The challenge for developing countries. International Journal of Human Sciences, 11(1), 1227-1237. doi: 10.14687/ijhs.v11i1.2894

high levels of violence and corruption" (UNODC, 2012, p8). The Salvador Declaration submitted to the Twelfth Congress on Crime Prevention and Criminal Justice also stresses on the challenge posed by environmental crime as newly emerging form of crime (UNODC, 2010). These developments are crucial steps to struggle against environmental crime, however, further steps should be taken by the states both in terms of technical capability to detect legislative regulations to prevent and sanction environmental criminals.

\section{Concluding Remarks}

Various local and global actors, ranging from peasants to international corporations, cause environmental degradation in all over the world. However, without taking into consideration that it stems from either local or global sources, the effects of environmental degradation are crucial for the entire world. So, environmental degradation is widely recognized as a global problem which needs both local and global solutions. The challenge shouldn't be recognized just as a local or a global problem. The solution of the challenges is possible with the appropriate policies at national and international levels. The focus should be both local people, who continue to their traditional behaviors and damage environment, and global powers leading to environmental exploitation in those countries.

Developing countries in cooperation with international organizations and civil society groups should combat with environmental crimes effectively. Instead of traditional methods of dealing with crimes they should use special environmental policing and prosecuting units to inspect and prosecute environmental violations, apply strict sanctions to the environmental criminals to prevent future generations from environmental crises.

The consequences of environmental degradation are very crucial for the sustaining of the world resources. Because of being lack of information or not having the ability and power enough to organize and combat it, the communities of the developing countries may not obscure exploitation of their resources by global companies or powerful countries. Therefore, the national governments and international bodies together should take necessary precautions and raise environmental awareness of the communities for a more peaceful world.

The struggle against environmental threat doesn't seem to be possible in only local or global level. The cooperation of both local and global forces is the most required action to effectively address the challenge of environmental degradation in the proper way in developing countries. 
Akbulut, A. (2014). Environmental degradation as a security threat: The challenge for developing countries. International Journal of Human Sciences, 11(1), 1227-1237. doi: 10.14687/ijhs.v11i1.2894

\section{References}

Barbier, E. (1997). The Economic Determinants of Land Degradation in Developing Countries. The Royal Society. London, 352, 891-899

Barnett, J. (2013). Global Environmental Change and Human Security. Annual Review of Environment and Resources. 38:373-386. 2013

Bowender, B. (1984). Energy Use Patterns in Rural Areas and Environmental Degradation in Developing Countries. Miami International Symposium on the Biosphere, Miami Beach, FL (USA), 23-24 Apr 1984

Bulte, E. H. \& Soest, D. P. V. (2001). Environmental Degradation in Developing Countries: Households and the (reverse) Environmental Kuznets Curve. Journal of Development Economics, 65,(1) , 225-235

Burns, R. G. and Lynch, M. J., (2004). Environmental crime: A sourcebook. New York: LFB Scholarly Publishing LLC.

Buzan, B. and Wæver O. (1998). Liberalism and Security: The Contradictions of the Liberal Leviathan. Copenhagen Peace Research Institute

Chandra, B. S., Nivas, B. T., \& Traxler, G. J. (1996). Irrigation Development and Environmental Degradation in Developing Countries. Water Resource Management, 10,(2), 129-146

Chatterjee, P. \& Finger, M. (1994). Power, Politics, and World Development. The Earth Brokers, Routledge, ch. 1.

Crowder, V., Lindley, W., Bruening, T., and Doron, N., (1998). Agricultural Education for Sustainable Rural Development: Challenges for Developing Countries in the 21st Century. Research for Education and communication service.

EIA. (2013). International Energy Outlook 2013, U.S. Energy Information Administration, retrieved in April 24, 2014 from http://www.eia.gov/oiaf/aeo/tablebrowser/\#release=IEO2013\&subject $=0$ -

IEO2013\&table=1-IEO2013\&region=0-0\&cases $=$ Reference-d041117

Fisher, D. \& Green, J. (2004). Understanding Disenfranchisement: Civil Society and Developing Countries' Influence and Participation in Global Governance for Sustainable Development. Global Environmental Politics, 4 (3).

Kütting, G. \& Rose, S. (2006). The Environment as a Global Issue. In Palgrave. Advances in International Environmental Politics. Edited by Betsill, M.M. at al., P. 129.

Lal, R. (2000). Soil Management in the Developing Countries. Soil Science, Vol. 165 (1), 57-72.

McMichael, A. (2000). The Urban Environment and Health in a World of Increasing Globalization: Issues for Developing Countries. Bull World Health Organ, Vol. 78 (9)

Miller, M. (2001). Tragedy for the Commons: the Enclosure and Commodification of Knowledge. The International Political Economy of the Environment. 2001.

UN. (2004). The Secretary General's High - Level Panel Report on Threats, Challenges, and Change. The United Nations Secretary General. retrieved on April 24, 2014 from http://www.unrol.org/doc.aspx?n=gaA.59.565_En.pdf

UNFPA. (2013) Population Trends. The United Nations Population Fund. retrieved on April 24, 2014 from https://www.unfpa.org/pds/trends.htm 
Akbulut, A. (2014). Environmental degradation as a security threat: The challenge for developing countries. International Journal of Human Sciences, 11(1), 1227-1237. doi: 10.14687/ijhs.v11i1.2894

UNODC. (2010). Salvador Declaration on Comprehensive Strategies for Global Challenges: Crime Prevention and Criminal Justice Systems and Their Development in a Changing World. Salvador, Brazil retrieved in April 24, 2014 from http://www.unodc.org/documents/crime-congress/12th-Crime-

Congress/Documents/Salvador_Declaration/Salvador_Declaration_E.pdf

UNODC. (2012). Other serious crimes, as defined in the convention, including new forms and dimensions of transnational organized crime. Report of the Secretariat, Sixth Session, Vienna, 15-19 October 2012 retrieved in April 24, 2014 from http://www.unodc.org/documents/treaties/organized_crime/COP6/CTOC_COP_2012_ 7/CTOC_COP_2012_7_E.pdf

Zhang, R. (2001). Economic Integration and Environmental Protection in the Asia Pacific. Asia Pacific Journal of Environmental Law. 6, (3-4), 215-238. 